\title{
Vocational Student's Attitude and Response Towards Experiential Learning in Mechanical Engineering
}

https://doi.org/10.1515/eng-2021-0027

Received Oct 02, 2020; accepted Nov 06, 2020

\begin{abstract}
This study evaluated the use of an experiential learning design for vocational education in mechanical engineering. The research objective is to analyze students' attitudes and responses after participating in learning activities using a worksheet designed according to Kolb's stages by considering Felder-Silverman's student learning styles. This research was conducted using a case study research employing qualitative data analysis. The data were collected using a purposive random sampling technique with 28 respondents in a 10th grade. The data were analyzed using descriptive qualitative analysis. The experiential learning activities were carried out concrete experience, reflective observations, abstract conceptualization, and active experimentation. It is shown that students have a positive attitude and response. Experiential activities help students in learning Basic of Mechanical Engineering and they enjoy participating in the learning activities. Experiential learning activities are considered to be fun, interesting, and easy to be understood. The students could relate the course material to real-life situations, which may benefit the students to enhance learning and connect the knowledge they learned to their own experiences. It is suggested that the experiential design is effectively used and could explore the relationship between learning theory and practice in Vocational High School.
\end{abstract}

Keywords: Experiential, Kolb Learning style, Mechanical engineering, Vocational

\footnotetext{
*Corresponding Author: Stephanus Fajar Pamungkas: Vocational Teacher Education, Universitas Sebelas Maret, Ir. Sutami Street 36A Surakarta, Jawa Tengah, Indonesia; Email: stephanusfajarp014@student.uns.ac.id Indah Widiastuti, Suharno: Vocational Teacher Education, Faculty of Teacher Training and Education, Universitas Sebelas Maret, Indonesia, Ir. Sutami Street 36A Surakarta, Jawa Tengah, Indonesia
}

\section{Introduction}

Vocational education shares key characteristics in teaching and learning which make it different from general education [1]. Vocational education aims to prepare students primarily working in certain fields of occupation. Vocational institutes tend to provide students with professional proficiencies and skills that are occupation-specific [2, 3]. Vocational education is emphasized on the mastery of knowledge, skills, attitudes, and values required for a specific job which obtained from learning by doing and handson experience [4]. Also, the learning characteristics of the vocational are a fairly large proportion of practical compared to theoretical activities [5]. Therefore, it is necessary that vocational education institutions adopting the learning approaches that could link subject matter with real-life activities and involve more senses (hearing, feeling, seeing, thinking and doing) [6] as well as creating a learning environment where students are more actively involved in the learning process, focusing on problems and design challenges and collaborating with other students [7]. This will have a greater impact on the students in enhancing their skills and competencies [8].

Experiential learning is an approach based on the acknowledgment that knowledge is created through the transformation of experience [9]. It is expected that the students will understand the learning material from what they hear, what they see, and what they do [10]. From a vocational education perspective, it might relevance since experiential learning could bridge conceptual knowledge with skills that are adapted to the future job in the real world [11]. It employs the student-centered learning approach through a learning cycle.

Learning comes from experience [12]. Learning happens everywhere, not just in the classroom. Taking the students beyond the classroom may nurture their creativity and imagination. Even though the classroom plays an important role in students' learning process, the teacher should facilitate the students to learn not only from their experiences but also from the experiences of the people

๑ Open Access. () 2021 S. Fajar Pamungkas et al., published by De Gruyter. 
surrounded. Learning combines the four basic elements of experiences, opportunities to practice, and embed those experiences into long-term memory, conversations, and interactions that occur with others, and reflection [13]. The purpose of experiential learning methods is to influence students by changing cognitive structures, changing students' attitudes, and broadening existing skills [14]. The student experience is considered a central role in the learning process. Kolb stated that effective experiential learning must go through four stages, namely concrete experience, reflective observation, abstract conceptualization, and active experimentation. Through this experiential learning method, students could develop meaningful and confident concepts in solving problems and making the right decisions through direct learning.

Experiential learning allows students to construct their own knowledge and experience, to acquire new knowledge and skills. It has become one of the innovations in satisfying the current educational needs [15]. It provides benefits including the ability to practice learning than memorizing [16], improving the ability to be an independent learner [17], improved students' problem-solving ability [18]. Besides, experiential learning with active learning modules helps students learn and their scores increase by $30 \%$ [19]. Difficulties encountered in complex learning material in engineering are possible to be overcome by actively involving students both inside and outside the classroom [20].

The basic concept learning activities of mechanical engineering in vocational schools are usually carried out by providing theories from textbooks and then students provide the answer to the problems provided [21]. Although this method could provide students with an understanding of basic theory by doing the exercises, the students may fail to learn how to apply the theoretical framework in practice [22]. Therefore, it is necessary to actively involve the students by integrating theory and practice. Experiential learning might facilitate vocational students to closely associate the practical value of the learning theoretical concepts.

This study investigated the application of experiential learning in vocational education majoring in mechanical engineering. A case study research was performed in a vocational school for a subject of Mechanical Engineering Design, whereas the learning outcome is to understand the basic concepts of mechanical engineering. The study was firstly initiated by designing and developing student worksheets that consider the students' learning styles. Identifying learning style preferences could be beneficial to the teacher to adjust methods, strategies, and teaching approaches [23]. Utilizing the student worksheets based on of experiential learning framework in vocational schools aims to support the student-centered learning approach.

This student worksheet is expected to be used as a tool in the active learning process that could provide direct experience for students in applying the principles or basic concepts of knowledge in mechanical engineering. The worksheet is designed to support the learning environment whereas students could participate in a concrete experience (feel), reflect on that experience (reflect), develop theories based on experiences and knowledge (think), and formulate a conclusion or solve a problem (do and apply).

The focus of this research is to evaluate the learning process within the experiential learning approaches for vocational engineering education. The research questions are as following:

- What are the attitudes and responses of students after participating in experiential learning activities?

- What is the students' experience after completing the experiential learning activities?

\section{Research Method}

\subsection{Research Design}

This research uses the case study field research method [24] with qualitative and quantitative approaches. The case research approach enables the exploration of phenomena and offers insightful meaning over factors captured in the study. It is believed that case study research will be the most appropriate technique in gaining in-depth knowledge of the practices of using worksheets in an educational setting. This study aims to evaluate the implementation of experiential learning design using student worksheets by considering student learning styles

Table 1: Demographics of the students [25].

\begin{tabular}{lcc}
\hline $\mathbf{N = 2 8}$ & & Frequencies \\
\hline Gender & Male & 26 \\
& Female & 2 \\
Age & & \\
& $15-16$ & 12 \\
Learning style preferences & 16 \\
& Active / Reflective & $28 / 0$ \\
& Sensing / Intuitive & $22 / 6$ \\
& Visual / Verbal & $23 / 5$ \\
& Sequential / & $14 / 14$ \\
& Global & \\
\hline
\end{tabular}


that enable students to explore the relationship between learning theory and practice.

\subsection{Research Sample}

This study was conducted in a 10th-grade vocational high school majoring in mechanical engineering in Indonesia. This class consisted of twenty-eight students ( 26 boys, 2 girls).

Table 2: Observation checklist the during learning process.

\begin{tabular}{|c|c|}
\hline Observation Aspects for Teacher & Observation Aspects for Student \\
\hline \multicolumn{2}{|l|}{ Concrete experience (feeling) } \\
\hline $\begin{array}{l}\text { - The teacher explains the material with situations or phenom- } \\
\text { ena in daily life, then conditions the learning situation to en- } \\
\text { courage students to think and convey an opinion. }\end{array}$ & $\begin{array}{l}\text { - Students pay close attention to the material, respond to re- } \\
\text { sponses related to phenomena in everyday life, and give an } \\
\text { opinion. }\end{array}$ \\
\hline \multicolumn{2}{|l|}{ Reflective observations (watching) } \\
\hline $\begin{array}{l}\text { - The teacher presents a general picture of the force through } \\
\text { power-point slides and learning videos. }\end{array}$ & - Students observe power-point exposure and video, carefully. \\
\hline $\begin{array}{l}\text { - The teacher shows visually through pictures of the forces that } \\
\text { are on the student worksheet. }\end{array}$ & $\begin{array}{l}\text { - Students observe and try to describe the picture provided on } \\
\text { the student worksheet. }\end{array}$ \\
\hline $\begin{array}{l}\text { The teacher directs students to observe objects or daily activ- } \\
\text { ities related to various forces. }\end{array}$ & $\begin{array}{l}\text { - Students observe objects or daily activities to then define and } \\
\text { describe them. }\end{array}$ \\
\hline $\begin{array}{l}\text { - The teacher demonstrates how to add force both graphically } \\
\text { and analytically. }\end{array}$ & - Students observe the teacher's demonstration. \\
\hline \multicolumn{2}{|l|}{ Abstract conceptualization (thinking) } \\
\hline $\begin{array}{l}\text { - The teacher conditions the learning situation to ask questions } \\
\text { actively and independently have been explained. }\end{array}$ & - Students ask questions related to learning material. \\
\hline $\begin{array}{l}\text { - The teacher encourages students to reason and explore infor- } \\
\text { mation and is asked to collect data to answer questions. }\end{array}$ & $\begin{array}{l}\text { - Students discuss to reason and explore information while col- } \\
\text { lecting data to answer questions. }\end{array}$ \\
\hline $\begin{array}{l}\text { The teacher directs students to describe the pictures provided } \\
\text { on the student worksheet regarding activities related to force. }\end{array}$ & $\begin{array}{l}\text { - Students discuss to describe the picture provided on the stu- } \\
\text { dent worksheet. }\end{array}$ \\
\hline $\begin{array}{l}\text { - The teacher directs students to be able to identify the types of } \\
\text { loads. }\end{array}$ & - Students discuss to identify the types of load. \\
\hline $\begin{array}{l}\text { The teacher encourages students to explain the lines of force } \\
\text { formed in each activity regarding the force and the require- } \\
\text { ments for drawing the lines of force. }\end{array}$ & $\begin{array}{l}\text { - Students explain the lines of force that are formed in each ac- } \\
\text { tivity about the force and the requirements for drawing these } \\
\text { lines. }\end{array}$ \\
\hline $\begin{array}{l}\text { - The teacher directs students to determine the force addition } \\
\text { formula. }\end{array}$ & - Students discuss in determining the force addition formula. \\
\hline $\begin{array}{l}\text { The teacher encourages students to explain the stages of the } \\
\text { drawing force. }\end{array}$ & - $\quad$ Students explain the stages in the drawing force. \\
\hline \multicolumn{2}{|l|}{ Active experimentation (doing) } \\
\hline $\begin{array}{l}\text { The teacher directs students to try to classify the data and } \\
\text { determine the relationship, then concluded with a sequence } \\
\text { from simple to more complex. }\end{array}$ & $\begin{array}{l}\text { - Students classifying the data and determining the relation- } \\
\text { ship then concluded with a sequence from simple to more com- } \\
\text { plex. }\end{array}$ \\
\hline $\begin{array}{l}\text { - The teacher encourages students to describe the activities or } \\
\text { objects observed on various forces. }\end{array}$ & - Students describing the activities or objects observed. \\
\hline $\begin{array}{l}\text { - The teacher guides students to draw the force manually using } \\
\text { drawing tools with parallelograms and polar methods. }\end{array}$ & $\begin{array}{l}\text { - Students draw forces manually using drawing tools with paral- } \\
\text { lelograms and polar methods. }\end{array}$ \\
\hline $\begin{array}{l}\text { The teacher directs students to carry out the work activities of } \\
\text { moving objects to identify the magnitude and direction of the } \\
\text { force while creating lines of force. }\end{array}$ & $\begin{array}{l}\text { - Students in groups do the work activities of moving goods or } \\
\text { objects. }\end{array}$ \\
\hline $\begin{array}{l}\text { - The teacher guides students to calculate the resultant force in } \\
\text { some cases. }\end{array}$ & - Students calculate the resultant force in several cases. \\
\hline $\begin{array}{l}\text { - The teacher demonstrates how to solve several problem cases } \\
\text { using AutoCAD software. }\end{array}$ & $\begin{array}{l}\text { - Students solve several problem cases using AutoCAD soft- } \\
\text { ware. }\end{array}$ \\
\hline $\begin{array}{l}\text { - The teacher helps students in reasoning and tries to classify } \\
\text { and write conclusions. }\end{array}$ & - $\quad$ Students try to reason and classify while writing conclusions. \\
\hline $\begin{array}{l}\text { - The teacher helps students to convey the results of conceptu- } \\
\text { alization about force and load. }\end{array}$ & $\begin{array}{l}\text { - Students convey the results of conceptualization about force } \\
\text { and load. }\end{array}$ \\
\hline
\end{tabular}


Their average age was about 17 years old. The majority of students' learning styles are active, sensing, visual. For sequential and global dimensions show balanced.

\subsection{Research Instruments}

Data were collected by using the following instruments: checklist from the class observations, questionnaires, and interviews with students. The instruments were reviewed by a mechanical engineering lecturer and mechanical engineering teacher.

\subsubsection{Class observations}

During the learning process, the teacher, who was also a researcher of the study and another observer, observed what the students were doing and their activities. The observation aspects during the learning would help the researchers examine students' engagement and also understand the real situation that occurs.

\subsubsection{Questionnaires}

After completing the experiential learning activities, students must fill out attitude and response questionnaires. The questionnaire consisted of 15 questions which were adopted from Chavan [26], to find out how students' attitudes and responses to the experiential learning process.

\subsubsection{Interview}

Interviews were conducted to explore students' responses to the experiential learning process using student worksheets. Fourteen students were selected for the interview, as these students were more willing to share their feelings.

The measurement scale of the questionnaire items was arranged using 5-point Likert scale: $1=$ strongly disagree, 2 = disagree, $3=$ neutral, $4=$ agree, and $5=$ strongly disagree. "Strongly disagree" means do not learn anything from the learning activity and "Strongly agree" means learn a lot from the learning activity.

The measurement scale of the observation instrument was arranged using two checklists: Yes or No. "Yes" means learning activities in the aspect observed have been carried out and "No" means learning activities are not carried out. For interviews using unstructured interviews con-
Table 3: Qualitative criteria for learning implementation [27].

\begin{tabular}{cc}
\hline Score Percentage Interval (\%) & Interpretation \\
\hline $82-100$ & Very Good \\
$63-81$ & Good \\
$44-63$ & Medium \\
$25-43$ & Bad \\
\hline
\end{tabular}

ducted based on the result of the student response an attitude questionnaire.

The learning process is analysed descriptively as a percentage of observations of the learning implementation.

Percentage score $=\frac{\text { Number of scores obtained }}{\text { Maximum number of scores }} \times 100 \%$

Determination of the predicate or validity criteria determined by the qualitative criteria.

\subsubsection{Data Analysis}

Before corroborating with the study of the observation sheet and interview, the first phase of the research carried over questionnaire responses to map students' learning styles preferences. Subsequently, elaborated with the result of qualitative data analysis through the student attitude and response questionnaire, observation of the learning process, and results of student interviews.

\section{Results}

The implementation of experiential learning design using student worksheets in Basic of Mechanical Engineering subjects with the topic of force and load has been carried out on odd 10th-grade students:

\subsection{Learning Objectives}

Force is one of the basic concepts of mechanical engineering design that must be understood by students majoring in mechanical engineering. The learning objectives on this topic, by feeling, seeing, thinking, and doing students are expected to be able to:

- Describe the various forces and loads.

- Describe how to draw and add the force.

- Draw the force line and do the force addition.

- Calculate the resultant force well and precisely. 


\subsection{Implement the Kolb's Experiential Learning Cycle}

Effective experiential learning is seen when students develop through the four stages of the Kolb cycle, using concrete experiences followed by observing activities or previous experiences that are interconnected, then developing concepts and generalizations which are then used to investigate and conclude.

The implementation of experiential learning design through the four stages of the Kolb cycle includes concrete experience, reflective observation, abstract conceptualization, and active experimentation on the force topic in detail explained as follows:

\subsubsection{Concrete Experience}

The first stage in experiential learning is the stage of concrete experience. At this stage, the teacher explains the material about forces and loads related to situations or phenomena in daily life, then conditions the learning situation to encourage students to think and write force definitions. In detail, the teacher gives apperception as follows:

- In everyday life, there are many things that are moving, such as motorbikes on the highway, trains, waterfalls, and so forth. Did you know that the cause of these objects to move is due to force?

- In addition, moving objects can also be stationary, such as tables and chairs that remain stationary, machines that are on the floor, and so on. Did you know that what moves an object from a stationary position to a motion is force?
- Otherwise, for example, the car moves with a certain speed and then the brakes so that the car stops. Did you know that the cause of the car stop is force?

\subsubsection{Reflective Observation}

At this stage, the teacher presents an overview of the force through power-point shows and learning videos. Students are asked to observe and examine the show and its explanation, then discuss what is meant by force based on the show.

Figure 1(1) shows about motorized vehicles moving on the highway. The cause of the motor movement is due to the force. Figure 1 (2) shows that the table and chairs are not moving. What moves the object from a stationary position to a motion is force. Figure 1 (3) shows that motorcyclists stop at the traffic light when the lights are red. The cause of the cessation of the vehicle is the force, namely the braking force. So, force is defined as everything because it causes a stationary object to move, to change its position from a state of being to a state of motion or vice versa from a state of being to a state of motion.

Besides, students are also asked to observe related phenomena related to the force contained in the student worksheet and then try to describe it. Students are also asked to observe objects and activities related to various forces to then define and describe them. Students also observe the types of loads and observe teacher demonstrations related to the sum of forces graphically and analytically.

Consider the following illustration picture!

Discuss with your seatmate, then describe what happened to the illustration of the picture

1

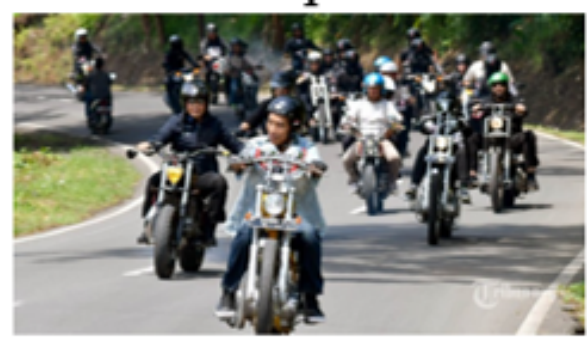

2

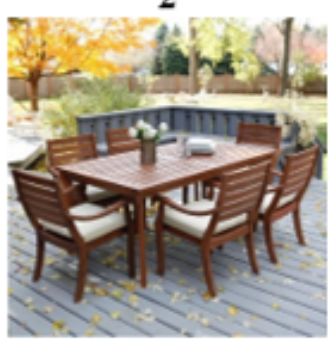

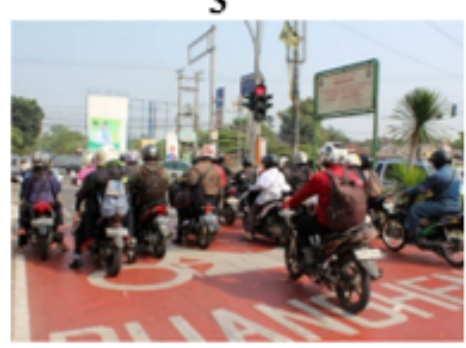

Figure 1: (1) (2) (3) Phenomena of the usual force that occurs in everyday life. 
Two forces each point at point $\mathrm{P}$ in the upright down direction with a force $\mathrm{F} 1=40 \mathrm{~N}$ and force $\mathrm{F} 2=30 \mathrm{~N}$ which point at the point $Q$ in the upright direction. If the distance $P Q=8 \mathrm{~m}$. Draw this force with a length of $1 \mathrm{~cm} \# 1 \mathrm{~m}$ and a scale of force $1 \mathrm{~cm} \# 10 \mathrm{~N}$ !

Answer:
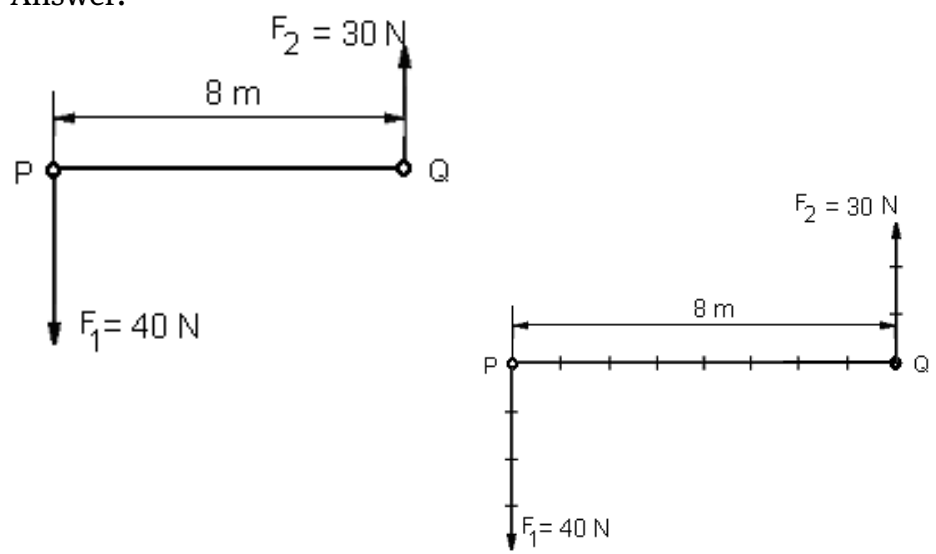

\section{Force Drawing Requirement:}

- Force catch point (work force, note point $\mathrm{P})$.

- Force scale ( $1 \mathrm{~cm} \# 1 \mathrm{~m} \# 10 \mathrm{~N})$, then to declare $40 \mathrm{~N}$ must be drawn lines along $4 \mathrm{~cm}\left(\mathrm{~F}_{1}\right), 30 \mathrm{~N} \rightarrow 3 \mathrm{~cm}\left(\mathrm{~F}_{2}\right), 8 \mathrm{~m} \rightarrow 8 \mathrm{~cm}$.

- Force direction, to show the direction of a force that is with arrows (look $F_{1}$ and $\mathrm{F}_{2}$ ).

- Long-scale, adjust to the condition of the paper to be used.

Figure 2: Exercise: Force Drawing.

\subsubsection{Abstract Conceptualization}

The abstract conceptualization stage directs students to learn to ask and reason. The teacher conditions the learning situation for students to ask questions actively and independently about the forces and loads that have been explained. Then, students are invited to reason as well as dig up information by gathering data to answer each question asked.

At this stage, students could describe activities related to force, could identify the types of forces and loads, describe the lines of force and the requirements for drawing force lines, determine the formula for adding the force and describing the stages in draw a force.

(a)
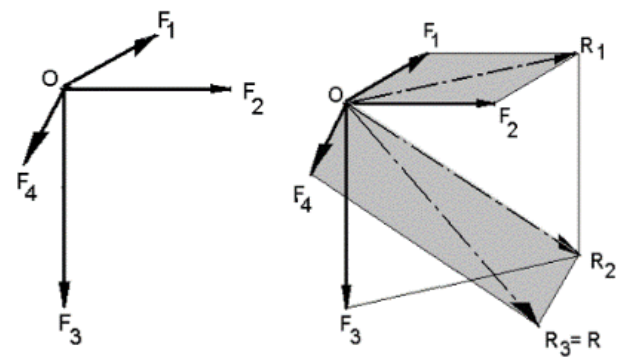

\subsubsection{Active Experimentation}

In the active experimentation stage, students try to do activities related to the force and try to communicate the results of the conceptualization of the force and the load.

Based on the data obtained from the activities at the abstract conceptualization stage, students are asked to try to classify the data and determine the relationship, then concluded with a sequence from simple to more complex about forces and loads.

Activities undertaken include describing objects and observational activities, drawing forces graphically using the parallelogram method and the polar method, carrying out the work of moving goods to identify the magnitude and direction of the force while creating lines of force. Also, it also calculates the resultant force on several sample case problems and solves some of the problem cases using AutoCAD software.

(b)

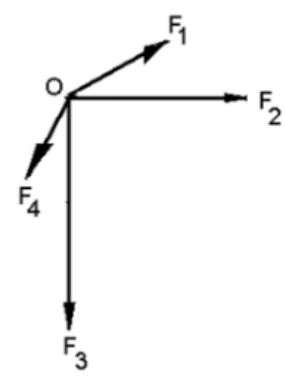

Figure 3: (a) Parallelogram method and (b) pole method. 
Two forces of each force $F_{1}=50 \mathrm{~N}$ with horizontal direction to the right and $\mathrm{F}_{2}=40 \mathrm{~N}$ force with the top right form a $30^{\circ}$ angle to the other,

1. Draw the two force and draw the resultant.

2. Calculate the resultant of the two froces.

Answer:

1. Draws two forces and resultant using an AutoCAD program (Graphical method)

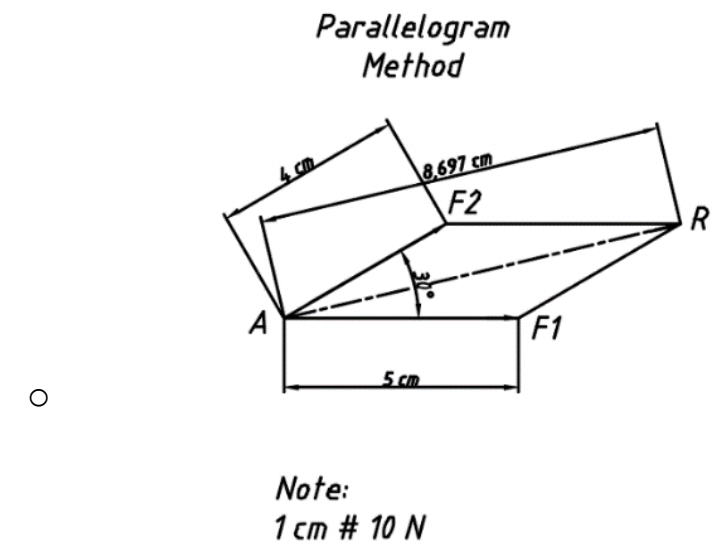

2. Analytical method

$$
\begin{aligned}
R & =\sqrt{50^{2}+40^{2}+2 \cdot 50 \cdot 40 \cdot \cos 30^{\circ}} \\
& =\sqrt{2500+1600+4000 \cdot 0.866} \\
& =\sqrt{4100+3464} \\
& =\sqrt{7564} \\
& =86.97 \mathrm{~N}
\end{aligned}
$$

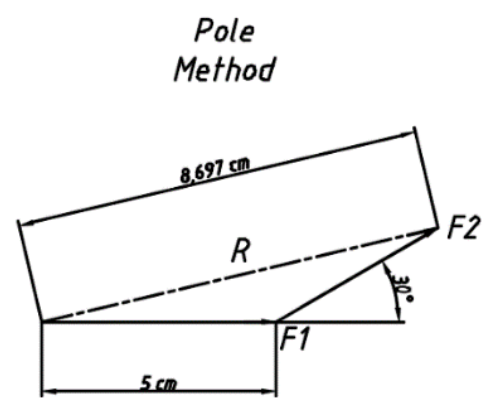

$$
\begin{aligned}
& R=8,697 \mathrm{~cm} \\
& \text { ataU } \\
& R=86,97 \mathrm{~N}
\end{aligned}
$$

So, Resultant Formula:

$$
\begin{aligned}
& \mathbf{R}=\sqrt{\mathbf{F}_{\mathbf{1}}^{\mathbf{2}}+\mathbf{F}_{\mathbf{2}}^{\mathbf{2}}+\mathbf{2} \mathbf{F}_{\mathbf{1}} \mathbf{F}_{\mathbf{2}} \cos \boldsymbol{\alpha}} \\
& \text { If angle }(\alpha)=90^{\circ} \text {, then } \cos \alpha=0
\end{aligned}
$$

Formula applies:

$\mathbf{R}=\sqrt{\mathbf{F}_{1}^{2}+\mathbf{F}_{2}^{2}}$

Figure 4: Activity: drawing and calculating the resultant.

\section{Purpose of Activity}

- Students can identify the magnitude and direction of the force correctly.

- Students can make force lines correctly.

Look at the following picture and text carefully!

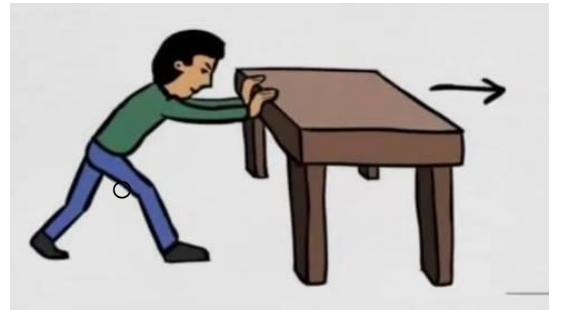

In work activities such as moving and lifting goods, there are forces that work. In the example picture the activity of moving a table above shows someone pushing a table. To be able to move the table, then someone needs a force that is greater than the force of the table down. Based on the description above, try to do the activity in class and observe the activity!

4.1 Identify the weight of the table and the forces acting on the activity!

4.2 Based on the identification results, describe the forces that work!

4.3 Present your experiment results and observations in front of the class with enthusiasm!

Figure 5: Activities to identify force strength and force direction. 


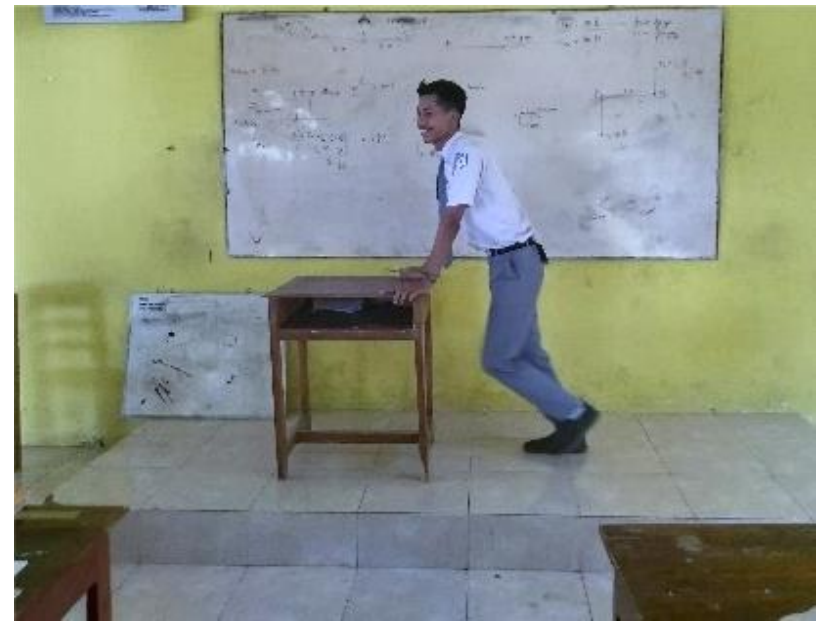

Figure 6: Students try to practice.

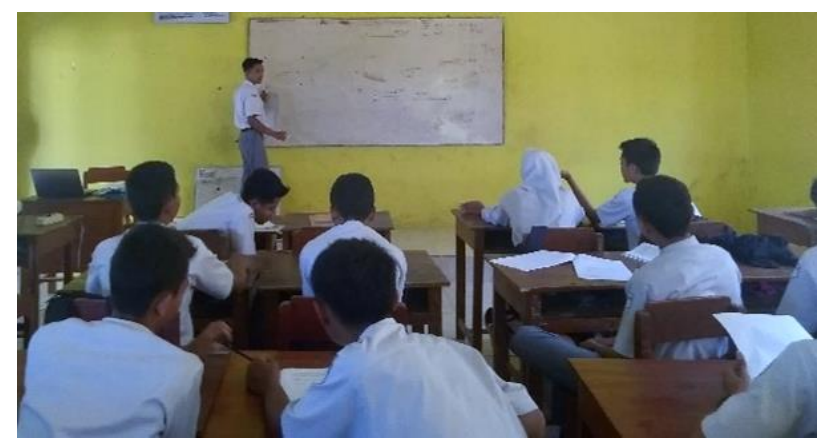

Figure 7: Student present practical results.

The implementation of experiential learning [28] is in line with the experiential learning design uses the Kolb cycle for students majoring in mechanical engineering with learning steps ranging from introduction, exploration, concept development and application to the topic of statistics, solid mechanics, and fluid mechanics. Besides, Mehrtash, Yen \& Balan [29] develop experiential learning that focuses on developing real-world experience in the form of classroom learning simulation as real experience on the topic of the automotive industry. The develop-

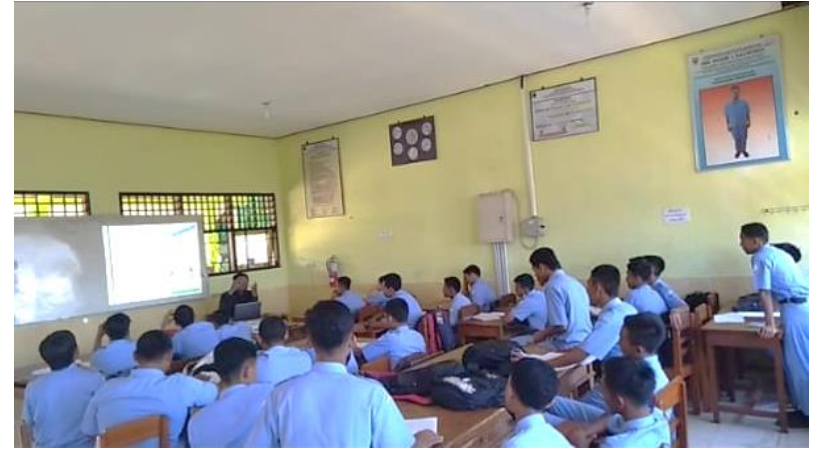

Figure 8: The situation during the learning process.

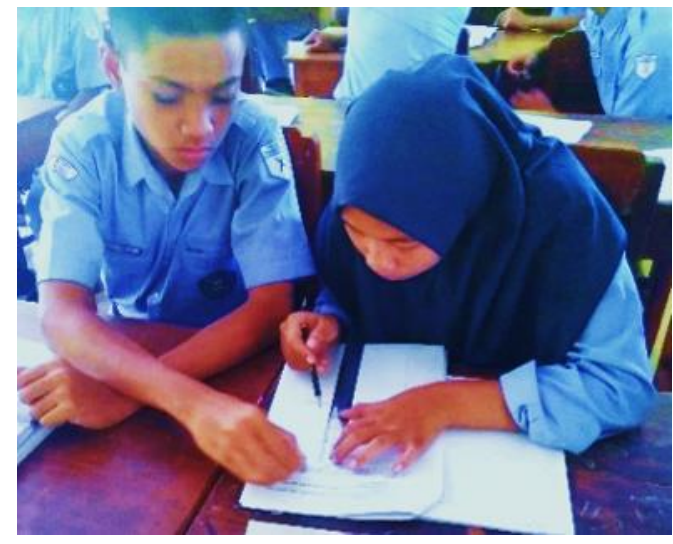

Figure 9: Discussion in class.

ment of experiential learning design is also based on four stages or the Kolb cycle.

\subsection{Observation Results of Learning Implementation}

Observation during the experiential learning activities or processes on the subject of Basic of Mechanical Engineering includes observations on the teacher or students starting from the preliminary activities, core activities and closing activities of learning.

Table 4: Percentage of observation results for experiential learning process.

\begin{tabular}{lccccccc}
\hline Aspects of activities & Max. & \multicolumn{2}{c}{ Score of observations } & \multicolumn{2}{c}{ Observation result (\%) } & Explanation \\
& score & Teacher & Students & Teacher & Students & & \\
\hline Preliminary activities & 40 & 38 & 37 & 95.00 & 92.50 & Very Good & Very Good \\
Core activities & 88 & 80 & 80 & 90.90 & 90.90 & Very Good & Very Good \\
Closing activities & 24 & 23 & 22 & 95.83 & 91.66 & Very Good & Very Good \\
Overall activities & 152 & 141 & 139 & 92.76 & 91.44 & Very Good & Very Good \\
\hline \multicolumn{7}{c}{ Average score } & \multicolumn{7}{c}{$\mathbf{9 2 . 0 9}$} & Very Good \\
\hline
\end{tabular}


Overall, the percentage of observations of the implementation of experiential learning design in Basic of Mechanical Engineering learning using worksheets was $92.09 \%$. This shows that experiential learning activities are carried out very well.

\subsection{Student Attitudes and Responses}

Data on attitudes and responses to the implementation of Kolb's cycle-based experiential learning activities in Basic of Mechanical Engineering subjects were conducted by students after they had followed the learning. Kolb's cyclebased experiential learning activities using student worksheets are carried out starting from the stages of concrete experience, reflective observation, abstract conceptualization, and active experimentation. Analysis of the evaluation of students' attitudes and responses becomes the basis for determining the effectiveness of experiential learning that enables students to explore the relationship between learning theory and practice.

Students' attitudes and responses are measured from the answers to 15 statement questionnaire items and interviews with some students about their knowledge (cognitive) and attitude (affective) experiences. The results of the student attitude and response questionnaire are shown in Table 5.

\section{Finding and Discussion}

Student responses and attitudes show positive responses after participating in experiential-based learning activities. It could be interpreted that experiential learning activities help them in basic learning Mechanical Engineering Design and they like to participate in learning activities. However, some students stated experiential learning activities were less challenging and too many tasks because they did not like too many tasks. The following are details of students' attitudes and responses:

\subsection{Interesting Learning}

Interest is a psychological condition that is characterized by increased attention, effort, and influence experienced on an object or topic in a particular situation, as well as a person's tendency to be involved in it [30].

The term 'interesting' is an effective reaction that can describe the momentary experience of someone who is attracted to a particular object with a lasting feeling that the object is fun and deserves further exploration [31]. For example, a student is interested in learning and enjoying the learning process, is more actively involved in the classroom, perceived values and cognitive functions of students are interrelated, and learning feels easy [32].

Table 5: Result of student attitude and response questionnaire

\begin{tabular}{clcc}
\hline No. & Item Question & Score & Interpretation \\
\hline 1 & Interesting learning. & 4.43 & Strongly Agree \\
2 & Learning is satisfying. & 4.21 & Strongly Agree \\
3 & Informative learning, gaining knowledge related to basic engineering design. & 4.43 & Strongly Agree \\
4 & Realistic learning activities (according to real circumstances) and related to the con- & 4.39 & Strongly Agree \\
& text of everyday life. & & \\
5 & The simple learning process (not complicated). & 4.18 & Strongly Agree \\
6 & Learning activities help develop my skills. & 4.54 & Strongly Agree \\
7 & The learning process is related (according to) to the development of my personal & 4.29 & Strongly Agree \\
& knowledge and skills. & & \\
8 & I feel actively involved in learning. & 3.93 & Agree \\
9 & I feel the learning activities challenge me. & 4.14 & Strongly Agree \\
10 & I like to participate in this learning activity. & 4.25 & Strongly Agree \\
11 & There has been a change in my level of confidence and knowledge. & 4.14 & Strongly Agree \\
12 & Experiential learning activities (activities and assignments) help me in integrating & 3.93 & Agree \\
& or connecting with the subject matter. & & \\
13 & I feel learning that it requires me to do an independent assessment. & 4.00 & Agree \\
14 & I learned things I did not know from this learning activity. & 4.21 & Strongly Agree \\
15 & I am happy to have participated in this experiential learning activity. & 4.39 & Strongly Agree \\
\hline & $\quad$ TOTAL AVERAGE & 4.23 & Strongly Agree \\
\hline
\end{tabular}


All students gave positive responses, the experiential learning activities they had participated in were interesting. They agree that experiential learning activities are interesting. Student responses related to this statement item are as follows:

\begin{abstract}
"Learning is interesting because teachers usually explain only in theory without using the media. Learning the Basics of Mechanical Engineering by using worksheets and PowerPoint is more interesting. Besides that, I didn't know before and didn't like the subjects related to counting, but after learning this I was more interested in learning calculations.”

"Interesting, because I like the lessons, learning is fun, the teacher's explanation is easy to understand, and learning isn't boring."

“Teacher's learning is easy to understand, the teacher's nature in teaching, fun learning is delivered seriously but relaxed (humor). So, I am interested in participating in every learning activity."
\end{abstract}

Based on the results of student interviews, experiential learning activities are interesting. The use of student worksheets and power-point media in learning makes a series of experiential activities more interesting. In addition, learning is interesting because learning is fun, and the teacher's explanation is easy to understand so it is not boring, and they are interested in participating in every learning activity.

\subsection{Satisfying Learning}

Satisfaction is defined as an emotional response caused by the quality of the results and the learning process related to students' knowledge and skills [33]. Satisfaction in learning is influenced by many factors including teaching methods, learning facilities or resources, attitudes, learning convenience, teacher communication skills and the ability to involve students in the learning process [34].

Students give positive responses to satisfying learning items. Overall students responded positively which means they agreed that the learning activities were satisfactory. Satisfying what is meant because the teacher's explanation is easy to understand, easy to understand, and can be accepted clearly. Student involvement and satisfaction can improve the quality of learning. Students' perceptions of learning are important parameters of the social and psychological aspects of the learning environment. Following are the responses of some students from the interview:

"Because the teacher's explanation is easy to understand, the material provided is easy to understand and could be accepted clearly.”

\begin{abstract}
"Because not all vocational learning can be easily understood, and with this learning, I can quickly know and understand Basic Mechanical Engineering Design.”

"I am comfortable in learning and how to teach a teacher in volves many students in the learning process in the classroom."
\end{abstract}

However, there are student responses that state that sometimes classroom conditions are less conducive, causing a lack of focus in participating in learning activities.

"Actually, I am satisfied and somewhat familiar with the material
and lessons, but sometimes the conditions of the class are crowded,
I become less focused on participating in learning."

\subsection{Informative Learning}

Informative is defined as everything that is informational and explanatory so that the recipient of the information understands what is being conveyed. Informative learning in this case is how information about the subject matter is communicated or conveyed to students.

Students agree that students receive well and easily understand information related to the subject matter of Basic Mechanical Engineering Design. Student responses based on the results of the interview are as follows:

\footnotetext{
"Learning is informative because it is supported using worksheets and e-learning (Schoology) in the learning process."
}

"Informative, because the way of delivering the teacher is clear and easy to understand and the use of worksheets helps me in learning."

"Informative, because the teacher explains it begins with experiences and activities related to the subject matter so that what I initially didn't know came to know and it made it easier for me to understand the lessons delivered by the teacher."

Informative learning is supported by the use of worksheets and e-learning in the form of Schoology, so learning activities are carried out in theory in class (face to face) and online learning.

\subsection{Realistic Learning Activities}

Realistic learning activities mean that they are in accordance with real conditions and are related to the context of daily life. Student responses state that the material contained in worksheets and those taught are related to activities in daily life. Therefore, it can be interpreted that experiential learning activities are realistic. Some student responses are as follows: 
"The material taught and in worksheet relates to activities that exist in daily life, for example about the force of lifting tables, pushing chairs, fruit falling from trees and other examples."

"There are examples of activities or activities that exist in our daily lives, and the teacher explains every activity related to the material being taught."

"Activities that are learned and carried out in class are appropriate to the real context and take examples of activities that exist in the surrounding environment."

\subsection{Simple Learning Process}

What is meant by simple is the learning process carried out in moderation and subject matter delivered in a language that is easily understood by students. The essence of learning is to simplify something (subject matter) that is complex so that the information or teaching material delivered by the teacher can be easily understood by students. Students also give positive responses namely simple experiential learning activities. That means they agree that experiential learning activities are simple and uncomplicated. Student responses related to this statement item are as follows:

"Actually, the learning material is quite complicated, especially in adjusting the results of manual calculations with pictures, but because using the worksheets and clear teacher explanations it is easier to understand and the way of working becomes simpler."

"Because learning is easy to understand and easier to apply when asked to answer and be able to explain to other friends."

"Learning is done simply, not complicated because I understand the material taught faster and the material is explained very coherently so that it is easier to understand."

"Because the teacher said that the easy things do not need to be complicated, for example in calculating the force, the formula provided is clear and the way to calculate is explained coherently and easily understood."

\subsection{Learning Activities Help Develop Skills}

Overall students responded positively which means they agreed that learning activities helped them develop skills in the Basic of Mechanical Engineering subjects. Following are the responses of some students from the interview:

"Because I am better able to do it independently every task and learning activity that is in Basic of Mechanical Engineering learning."

\begin{abstract}
"With the worksheet, all the tasks are done alone or discussing with friends and need to think in the process of the worksheet so that my knowledge and skills increase."
\end{abstract}

"Because the activities carried out during the learning process make me want to try it myself and trigger me to become more skilled."

Students respond that they feel their skills have improved which is marked by their ability to do each task and each learning activity independently.

\subsection{Learning Process in Accordance with Knowledge and Skills Development}

Students respond that the learning process is in accordance with the development of students' knowledge and skills. Student responses based on the results of the interview are as follows:

"Yes, because my knowledge and skills have increased after attending the learning process."

"It is appropriate and developing because from the beginning I have not been able to now become and be able to understand the Basic of Mechanical Engineering material."

"Because it really enhances my knowledge and skills, learning is fun and exciting, friends and teachers can be invited to discuss together."

\subsection{Active Student Involvement in Learning}

Positive responses of students can be interpreted that they are actively involved in the experiential learning process. Some student responses are as follows:

"Because I like the lessons, so I am more active starting from answering the questions asked, discussing, and determining the correct answer or not."

"Usually I rely on friends (cheating), but now I feel more challenged actively trying to work on and answer each question myself."

"Because I can answer the questions and all the tasks in the worksheets I do as well as my curiosity to add to each learning session."

"Because the teacher instructs to do, draw, do activities, and count independently.”

"I was quite involved because I felt I was not smart enough so sometimes I was involved sometimes not, sometimes I could answer questions, and sometimes I couldn't answer." 


\subsection{Challenging Learning Activities}

Challenging learning activities means students feel challenged to complete each experiential learning activity. Some student responses are as follows:

"I feel challenged to know and better understand the Basic of Mechanical Engineering subjects."

"Because the teacher gives questions to be answered, they range from simple to rather complicated ones. In addition, it provides examples of activities that are available and can be carried out in daily life, so that I feel more challenged to complete learning."

"Because at first I couldn't and became more able, sometimes jealous of other friends who could and who were smarter made me motivated to be able to and challenge me to be able to think for myself."

However, in this statement item, there is one student who responded disagree. The student argues that learning activities are less challenging and argue that activities related to practice if possible are added.

\subsection{Participation in Learning Activities}

Students give a positive response and they like to participate in experiential learning activities. Student responses related to this statement item are as follows:

"I like it because I am an active person. So, it is in accordance with the activities carried out in this study."

"Because learning is interesting, conditions are comfortable in the classroom, and there are friends and teachers who help in learning."

"I like it because for example there are problems I do and calculate by myself, when I find answers to questions then I discuss with friends."

"Because learning is easy to understand and easy to accept, and I want to show that I am a student who is active in learning and understands what is being learned."

"I like being happy with the lessons, because they are easy to understand, and I find it easier to understand the material being taught and my knowledge and skills become better."

\subsection{Changes in the Level of Confidence and Knowledge}

The students gave positive responses namely experiential learning activities that they had participated in were able to change their level of confidence and knowledge. They agree that experiential learning activities can increase their knowledge and confidence in the classroom. Student responses related to this statement item are as follows:

"Yes, I am more confident in answering the questions given."

"Yes, I feel that I can calculate, I can't, try, then I can, and I can, then I become challenged and more confident if I can understand the Basic of Mechanical Engineering subject matter."

"Yes, because I know better, and when answering the questions correctly I am more confident in answering both the questions in the worksheet and the questions from the teacher."

"Yes, I am more confident in my abilities, more confident in answering questions, in discussions, and in explaining to other friends."

"There is increased knowledge, curiosity increases, dare to ask, dare to answer, and do it yourself, and presentations in front of the class."

\subsection{Experiential Learning Helps in Integrating with Learning Materials}

Students respond positively to the items of the relationship between learning activities and subject matter. They agree that experiential learning activities (activities and assignments) help them in integrating or connecting with the material being taught. Responses to the results of student interviews related to this item are as follows:

"Activities and assignments help me understand from material that is difficult to understand by doing those tasks become easier to understand."

"The assignments given are almost the same as the material taught."

"Yes, because the tasks and activities carried out are the same as the material given in class."

"Yes, because every learning activity can be practiced and often found in daily life."

"Because Basic of Mechanical Engineering learning using worksheet is interconnected and more concise. So, it is easy to understand."

However, on this item, there was one student who gave a response that did not agree with the reason that the assignments were indeed in accordance with the subject matter, but according to him the assignments were given too much, "I don't really like many assignments." 


\subsection{Learning Requires Conducting an Independent Assessment}

Students agree that experiential learning activities require them to carry out assessments independently. However, there were two students who responded disagreeing with this item. Student responses based on the results of the interview are as follows:

"Yes, because I am required to do active and independent learning activities. I can judge my own answers and not depend on my friends.”

"I feel because I do it myself if there are questions, tasks, activities, and I can finish then I judge I can. But when I haven't been able to finish it, I don't fully understand."

"I understand the extent to which I understand the material provided.”

Students who respond disagree on the grounds that they are unsure of what they are doing and doing, and in doing each task and activity are still assisted by other students.

\subsection{Learning Unknown from Learning Activities}

Students give positive responses, namely, students learn things that are not yet known from the learning process. Positive responses were shown. Students agree that they learn new things and subject matter that they have not previously gotten from experiential learning activities. Student responses related to this statement item are as follows:

"Yes, because before I did not know and after learning to know."

"Yes, because this learning activity is new in my opinion, and there are several sub-topics that have never been taught before."

"Yes, for example when calculating the resultant force analytically (calculation) can be proven by graphical (drawing) either manually or using the AutoCAD program.”

\subsection{Response After Following Experiential Learning Activities}

The students gave a positive response that they were happy after participating in experiential learning activities using the worksheet on Basic of Mechanical Engineering subjects. Students agree that experiential learning activities are fun. Student responses related to this statement item are as follows:

"Happy, because it is more interesting, easier to understand and the way to deliver teachers in class is simple (not complicated)."

"Happy, because I got to know and understand more about the lesson.”

"Yes, because Basic of Mechanical Engineering learning is different from the others, the difference is using worksheet and e-learning (Schoology) and it makes me happy to take part in learning. In addition, the teacher explains coherently and is easily understood."

"Yes, because this lesson really helped me to be more able and to develop my knowledge and skills."

"Happy, because I'm actively involved in learning, fun learning, assignments, and activities that are carried out in accordance with the material taught, friends and teachers are easy to discuss."

In general, students provide responses and responses to the application of Kolb cycle based experiential learning using student worksheets on Basic of Mechanical Engineering subjects that:

- The worksheet is very helpful in learning because there are materials related to the context of daily life.

- Learning is easy to understand, learning is serious but also not too tense (relaxed).

- Learning using worksheets is easier to understand and there are opportunities to work in groups and discussions. So, it is easier to know and easy to understand.

- Learning is easier to understand and interesting because the teacher's explanation is easy to understand.

- Learning in class is interesting, fun, has humor and makes think more, moreover it is done with practice and theory alone is more difficult to understand.

- Basic of Mechanical Engineering learning can be applied in everyday life and encourage me to be more active in learning also adds to my knowledge and makes me more independent in learning and doing every task given.

Overall, the attitudes and responses of students obtained positive results in experiential learning activities. Positive attitude and response $98.8 \%$ of students reinforce the opinion that experiential learning activities help students in learning (cognitive) and students like to participate in learning activities carried out (affective). The results of students' attitudes and responses research are in accordance with [26] which states that $96 \%$ of students say 
experiential learning helps students in learning and they like to participate in experiential learning activities.

\section{Conclusion}

Implementation of experiential learning design uses student worksheets in Basic of Mechanical Engineering subjects on the topic of force and load based on the four Kolb cycles, namely concrete experience, reflective observations, abstract conceptualization, and active experimentation. The observation results of experiential learning design implementation showed a percentage of $92.09 \%$ which meant that experiential learning activities were carried out very well. Positive student responses and attitudes towards experiential-based learning activities. $98.8 \%$ of students showed a positive response. It means that experiential learning activities help students in learning Basic of Mechanical Engineering (cognitive) and they like to participate in learning activities (affective) and are effectively used in learning as well as to explore the relationship between learning theory and practice. However, there are also students who respond that experiential learning activities are less challenging and too many tasks because they do not like too many tasks. Experiential learning is appropriate with characteristics of vocational education that is based on learning by doing and a fairly large proportion of practical activities. So, experiential learning is suitable to be applied in vocational education because students could learn more actively by directly practicing activities that are relevant to the theory being taught. In addition, these practical activities could also be applied in daily life and in accordance with the conditions around them.

\section{References}

[1] Jalinus, N., \& Nabawi, R. A. (2019). A comparison of the problemsolving skills of students in PjBL versus CPjBL model: An experimental study. Journal of Technical Education and Training, 1(11), 36-43.

[2] Benavot, A. (1983). "The rise and decline of vocational education." Sociology of Education, Vol. 56, No. 2, pp. 63-76.

[3] Chen, J.K. and Astor, R.A. (2011), "School engagement, risky peers, and student-teacher relationships as mediators of school violence in Taiwanese vocational versus academically oriented high schools", Journal of Community Psychology, Vol. 39 No. 1, pp. 10-30.

[4] Djojonegoro, W. (1998). Pengembangan Sumber Daya Manusia: Melalui Sekolah Menengah Kejuruan (SMK). Jakarta: PT Jayakarta Agung.
[5] Pamungkas, S.F., Widiastuti, I., \& Suharno. (2020). 21st Century Learning: Experiential Learning to Enhance Critical Thinking in Vocational Education. Universal Journal of Educational Research. Vol. 8 (4), pp. 1345-1355. doi:10.13189/ujer.2020.080427.

[6] Engr. Amaechi, O. J., \& Thomas, C. G. (2016). Strategies of effective teaching and learning practical skills in technical and vocational training programmes in Nigeria International Journal of Scientific Research Engineering \& Technology (IJSRET), 5, 598603.

[7] Pinder-Grover, T.A. (2013). Active Learning in Engineering: Perspectives from Graduate Student Instructors (Paperat ASEE Annual Conference \& Exposition Atlanta Georgia.

[8] Villiers, R. De. (2010). The incorporation of soft skills into accounting curricula: Preparing accounting graduates for their unpredictable futures. Meditari Accounting Research, 1(2), 1-22.

[9] Kolb. (1984). Experiential Learning: Experience as the Source of Learning and Development, pp. 288.

[10] Smart, K. L., \& Csapo, N. (2007) Learning by doing: Engaging students through learner-centered activities. Business Communication Quarterly, 70 (4), 451-457.

[11] Efstratia, D. (2014). Experiential Education through Project Based Learning. Procedia - Social and Behavioral Sciences, 152, 12561260.

[12] Zan, G. D., Toni, A. F. D., Fornasier, A., \& Battistella, C. (2015). A Methodology for the Assessment of Experiential Learning Lean: The Lean Experience Factory Case Study. European Journal of Training and Development. 39 (4), 332-354.

[13] Jennings, C., \& Wargnier, J. (2010). Experiential Learning: A Way to Develop Agile Minds in the Knowledge Economy?. Development and Learning in Organizations: An International Journal. 24 (3), 14-16.

[14] Baharuddin \& Wahyuni, N.W. (2007). Teori Belajar \& Pembelajaran. Yogjakarta: Ar-Ruzz Media.

[15] Warnick, G. M. [2014]. An Experiential Learning Approach to Develop Leadership Competencies in Engineering and Technology Students an Experiential Learning Approach to Develop Leadership. American Society for Engineering Education.

[16] Bangs, J. (2011). "Experiential learning In an Organizational Leadership Program," Journal of College Teaching \& Learning, Vol. 8, No. 10, pp. 29-34.

[17] Jiusto, S. \& DiBiasio, D. (2006). Experiential learning Environments: Do They Prepare Our Students to be Self-Directed, LifeLong Learners? Journal of Engineering Education, vol. 95, no. 3, pp. 195-204.

[18] Hulaikah, Mifta et al. (2020). The Effect of Experiential Learning and Adversity Quotient on Problem Solving Ability. International Journal of Instruction. Vol. 13 (1), pp. 869-884.

[19] Brown, A., D. Jensen, J. Rencis, K. Wood, J. Wood, C. C. White, K. K. Raaberg, \& J. Coffman, (2012). Finite Element Learning Modules as Active Learning Tools. Advances in Engineering Education, 3, 29.

[20] Linsey, J., Talley, A., White, C., Jensen, D., \& Wood, K. (2009). From Tootsie Rolls to Broken Bones: An Innovative Approach for Active Learning in Mechanics of Materials. Advance in Engineering Education. pp. 1-23.

[21] Xueyi Li, Wei Junying, Ding Shuhui, Wang Quanwei. (2017). Teaching Mode of Mechanical Design Course based on Simulation Analysis Technology. International Journal of Emerging Technologies in Learning. Vol. 12 (7). p. 112-123. 
[22] Huizenga, C., Arasteh, D.K., \& E. Finlayson, Teaching Students About Two-Dimensional Heat Transfer Effects in Buildings, Building Components, Equipment, and Appliances Using THERM 2.0. (ASHRAE Transactions, 1999), pp. 105.

[23] Pamungkas, S.F., Widiastuti, I., Suharno. (2019). Kolb’s Experiential Learning as an Effective Learning Model in Creative Product and Entrepreneurship Subjects. 07/2019; 2(1):27., DOI:10.20961/jomeve.v2i1.28352

[24] Hamilton, Lorna \& Whittier, C. Corbett. (2014). Defining Case Study in Educational Research. SAGE Publications Ltd. London. SAGE Research Method.

[25] Pamungkas, S.F., Widiastuti, I., \& Suharno. (2019). Kolb's Experiential Learning for Vocational Education in Mechanical Engineering: A Review. Exploring Resources, Process and Design for Sustainable Urban Development: Proceedings of the 5th International Conference on Engineering, Technology, and Industrial Application (ICETIA) 2018; 06/2019, DOI:10.1063/1.5112427.

[26] Chavan, Meena. (2011) Higher Education Students' Attitudes Towards Experiential Learning in International Business. Journal of Teaching in International Business. 22:2, 126-143, DOI: 10.1080/08975930.2011.61567.

[27] Asih, S.S. \& Renggani. (2019). Intensity Attention of Parents and Communication in Families to Learning Outcomes. Advances in Social Science, Education and Human Research. Vol. 303, pp. 180-184.

[28] Lyons, J. S. \& Brader, J. S. (2015). Using the Learning Cycle to Develop Freshmen's Abilities to Design and Conduct Experiments. International Journal of Mechanical Engineering Education. Ijj.sagepub.com
[29] Mehrtash, M., Yuen, T. \& Balan, L. (2019). Implementation of Experiential Learning for Vehicle Dynamic Automotive Engineering: Roll-over and Fishhook Test. The 12th International Conference Interdisciplinarity in Engineering. https://creativecommons.org/licenses/by-nc-nd/4.0/ Science Direct Procedia Manufacturing 32, pp.768-774.

[30] Harackiewicz, Judith M., Smith, Jessi L., Priniski, Stacy J. (2016). Interest Matters: The Importance of Promoting Interest in Education. Policy Insights Behav Brain Sci. 3(2), 220-227.

[31] Hidi S., \& Renninger, K. A. (2006). The Four-Phase Model of Interest Development. Educational Psychologist. 41:111-127. DOI: 10.1207/s15326985ep4102_4.

[32] Ainley, M. (2006). Connecting with Learning: Motivation, Affect and Cognition in Interest Processes. Educational Psychological Review. 18:391-405. DOI: 10.1007/s10648-006-9033-0.

[33] Browne, Beverly A., Kaldenberg, Dennis O., Browne William G. \& Daniel J. Brown. (1998). Student as Customer: Factors Affecting Satisfaction and Assessments of Institutional Quality. Journal of Marketing for Higher Education. 8 (3), p. 1-14, DOI:10.1300/J050v08n03_01.

[34] Choudhury K. (2012). A Model of Quality in the Education Service Sector: An Application of TOPSIS. Journal of Strategic Management Education. 8 (2), 93-114. 